\title{
Drivers of logistics outsourcing practices in tea processing firms in Bomet County
}

\author{
${ }^{1}$ Dennis Wasike Ngonela, ${ }^{2}$ Carolyne Mwaniki, Pr Gregory Namusonge \\ ${ }^{1}$ Msc Student, Jomo Kenyatta University of Agriculture and Technology \\ ${ }^{2}$ Msc Student, Jomo Kenyatta University of Agriculture and Technology \\ ${ }^{3}$ Lecturer School of human resource development Jomo Kenyatta University of Agriculture and Technology
}

\begin{abstract}
The study sought to determine the drivers and practices of logistics outsourcing practices among tea processing firms in County. The study surveyed the logistics outsourcing practices being used by the tea processing firms in Bomet by collecting primary data through self administered questionnaire. Data was analyzed using descriptive statistics. The study found out that the firms use several logistics outsourcing practices with own or in-house transport being the most common. All the tea processing firms that were surveyed outsourced some of their logistics functions though at varying degrees. Logistics outsourcing among the tea firms was most prevalent in operations such as warehousing, fleet management, fleet operations, transport and distribution. The study concluded that there exists a drive towards the use of logistics outsourcing as a strategy to reduce costs, to pursue core business activities, reduce risks and gain competitive advantage. The survey also established some of the challenges faced by the firms as they moved to outsource their business activities; these included loss of control of the activities, loss of employee loyalty, industrial unrests, switching costs, loss of information to competitors and resistance to change by the stakeholders.
\end{abstract}

\section{Background of the Study}

The global nature of business has forced companies to recognize the critical role of back end operations of a logistics supply chain. As the firms focus on production, marketing, Human Resource Management and finance, greater attention is required to achieve customer satisfaction through efficient logistics (Watson and Pitt, 1989). Due to improved Information and Communication Technologies (I.C.T), logistics has become an integral part of e-commerce and e-business. Logistics is a source of core competency and a linking tool for attaining competitive advantage (Muller, 1993).

Emerging trends indicates that Logistics management has shifted from the traditional back end operation to a strategic boardroom activity (Stock and Lambert, 2009). These trends have come to the fore as a result of various reasons such as; Globalization which is making national economies more and more integrated into the Global economy, International trade which is expanding at an exponential rate, technological advancement has become an integrating force, informed customers whoare demanding value for their money, marketers are experiencing competitive pressure and businesses struggling not only for growth but also for survival (Sople, 2011).

\subsection{Statement of the Problem}

Organizations have chosen various ways of achieving the objectives of cost reduction and eventually improving on the productivity and overall performance. The common strategies used to achieve this include; outsourcing, restructuring, staff retrenchment, asset reduction, mergers and acquisitions among others (Stock and Lambert, 2001).

Outsourcing of the logistics function is today viewed as; a means of cost saving, a tool to competitive advantage, a risk medium, a strategic competitive tool as well as a means to creation of synergistic partnerships and strategic alliances among firms (Stock and Lambert, 2001). In the past firms focused on "Win -lose" or arm length relationships, today however, firms are concerned about the wellbeing of partner firms. Rather the firms are practicing symbiotic relationships where all are beneficiaries ("WIN -WIN" situation).

An increasing number of companies are outsourcing their functions, particularly in the non-core business areas. The tea industry is characterized by a large demand for logistics services given the perishable nature of tea and the demand for very high standards in handling and storage before and after processing. According to the Kenya Tea Board, tea manufactures and processors have to adhere to set standards failure of which their operating licenses will be revoked.

Tea processors in Bomet County are faced with similar challenges in the management of logistics for example in transportation of employees, raw tea as well as processed tea, storage, warehousing and shipment to international markets. Generally it is important to note the fact that tea plucking and processing is a delicate process. During tea plucking peak seasons, there is a big logistics problem both for the raw tea leaves, as well 
as the processed products. Outsourcing is therefore the strategic management tool to use as a means to cost reduction, improved service delivery, enhanced efficiency and effectiveness (http://www.softkenya.com).

\subsection{Objectives of the study}

In this sub-section, the researcher provides the general objective of the study. The specific objectives helped the achievement of the objectives.

\subsection{General Objective}

The general objective of this study is to determine the drivers of Logistics Outsourcing practices in tea processing firms in Bomet County.

\subsubsection{Specific Objectives}

The Specific Objectives of this study are:

i. To establish how financial incentives drives tea processing firms in Bomet County to outsource logistics.

ii. To find out how focus on core competence motivates tea processing firms in Bomet County to outsource logistics.

iii. To determine how globalization drives tea processing firms in Bomet County to outsource logistics.

iv. To ascertain why improved productivity drives tea processing firms in Bomet County to outsource logistics

v. To establish the logistics outsourcing practices among tea processing firms in Bomet County.

\subsection{Research Questions}

This study answered the following research questions:

i. What are the financial incentives driving tea processing firms in Bomet County to outsourcelogistics?

ii. How does the focusing on core competence motivate tea processing firms in Bomet County to Outsource Logistics?

iii. Why does globalization drives tea processing firms in Bomet County to outsource logistics?

iv. How does improved productivity motivate tea processing firms in Bomet County to outsource logistics?

v. What are the logistics outsourcing practices used in tea processing firms in Bomet County?

\section{Introduction}

Baily, 1998, many organizations today are turning to external procurement, where we even find that functions such as transport, accounts, computer services, even purchasing can be outsourced. This gives the company employees time to perform their duties to the company's satisfaction and this improves the organizational performance which is every company's objective to achieve competitive advantage. Eyaa, 2006, defined outsourcing as a decision by firms to have an external supplier to take over an activity that would have otherwise been performed in-house by organization employees. Usually organizations look for the best service providers to whom to outsource their work, this gives them a chance to get their work done by experts which means good quality work leading to a good company name. Lysons and Gillingham, 2003, states that outsourcing is the strategic use of resources to perform activities traditionally handled by internal staff and their resources. It is a management strategy by which an organization outsources major non-core functions to specialized and efficient service providers to help the organizations perform best where it is best capable.

\subsection{Conceptual Framework}

The figure 2-2 below illustrates the conceptual framework of the study, identifying the dependent and independent variables which will form the basis of the study.

Figure 1.

Independent Variable $\quad$ Dependent Variable

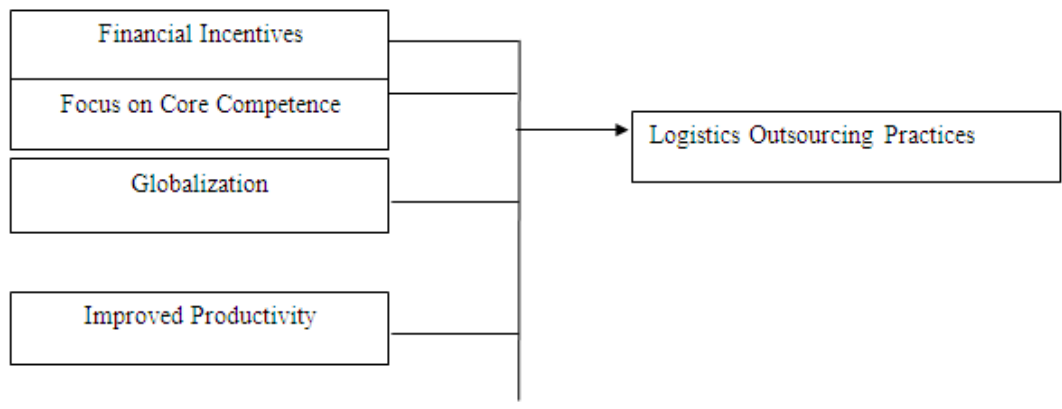




\section{Financial Incentive}

According to Frankwood and Sangster, the company has a limited investment budget. The funds must be used for investments in the core activities which are long term decisions and leave non-core activities to outside providers to do them on behalf of the organization.

\section{Focus on Core Competencies}

For companies to be able to survive in today's competitive markets, they must focus on their core competencies and adopt outsourcing as a strategic solution to improve quality of service and reduce costs of important as well as non-core processes. Using the strategic 3PL service providers, in integrated logistics, companies the world over reported gains such as cost reduction, logistic assets and order cycle time. Management of logistics roles in the present day organizations involves making decisions for the complete distribution of goods and services (Watson and Pitt, 1989) with a goal of maximizing value. Modern managers are aware that competitive advantage can be achieved from the delivery process as well as through the product Muller, (1991) \& Foster, (1994).

According to a survey conducted by Lieb\& Randall (1996), it was found out that the top executives of 3PL service providers perceived growing customer demand in outsourcing. The advent of logistics contracting role has become a motivation in drawing the attention of logisticians towards this astute move to outsourced logistics (Gooley, 1994). If well managed, Outsourcing can contribute to profitability by enabling the firm members to gain a competitive edge, concentrate on core business functions by adding value to products, improved customer service, venturing into new markets and providing quality resources Foster \& Muller, (1990).

\section{Improved Productivity}

The other driver of outsourcing is improved productivity. Productivity improvement results from the level of specialization and expertise by the 3PL. As identified in studies in the United States of America (USA), companies outsource their services in order to improve customer service, efficiency and greater service integration, economies of scale and cost savings, access to competencies and global supply and solutions (Konezny \& Beskow, 1999; Burns et al, 2001; Langley et al, 2002). A 3PL with the necessary logistics infrastructure, and expertise performs recurring activities that would have otherwise have been performed inhouse in the long or short term with risk, gain and shared information.

The 3PL assumes the responsibility to improve productivity as a means to assuring the contracting firm that the benefits of outsourcing out-match those of in-house logistics management. This is according to a survey conducted with top 500 organizations in India which resulted to; cost reduction; improved return on assets; improved inventory turns; increased shareholder returns and improved customer service (Sohail, Bhatnagar and Sohal 2006).

\section{Globalization of Businesses}

Globalization of businesses is viewed as the most prominent driver of outsourcing (Sheffi, 1990). These effects can be attested by the growth of global markets and international outsourcing practices. Globalization of business activities has further led to increased pressure on the logistics practitioners as they seek to uphold the course of their business undertakings (Cooper, 1993 and Fawcett et al, 1993).According to (Bradley, 1994), the effects of global markets have also led to complex supply chains hence involving more and more experienced logistics practitioners in international logistics operations. These practitioners bring with them specific know how on cross boarder trading, developed infrastructure of the destination countries which includes information and communication mechanisms as well as developed channels of distribution.

\subsection{Key factors necessary for outsourcing \\ 2.2.1 Management Support}

Peter Jeans 2008 suggests that when it comes to logistics outsourcing, it should be supported by all departments of the organization so as to get the best of the benefits of outsourcing in the organization. To achieve success, we always have to stand together to share ideas for better organizational performance. Garry Petty says that any activity in the company done without management consent and support is a manifestation of failure in that activity. This shows how much important management support and involvement is in all company activities outsourcing inclusive.

\subsection{Change management system and culture}

According to Terry Paulson, Change management is a systematic approach to dealing with change, both from the perspective of an organization and on the individual level. A somewhat ambiguous term, change management has at least three different aspects, including: adapting to change, controlling change, and effecting 
change. A proactive approach to dealing with change is at the core of all three aspects. For an organization, change management means defining and implementing procedures and/or technologies to deal with changes in the business environment and to profit from changing opportunities.

\subsubsection{Objectives, environmental scanning and expectations of outsourcing programme}

Properly defined performance criteria for an outsourcing engagement are objective, quantifiable, and collectible at a reasonable cost, and should be metrics which can be benchmarked against performance of other organizations and providers (Parzinger and Lado 1997; Kleepes and Jones 1999).

Early in the evaluation, persons must be identified as to who will take leadership responsibility, perform the analysis, and make the decisions. Adequate supporting infrastructures, commitment by top management, and development of objective performance criteria were among the factors contributed to successful outsourcing projects

Properly defined performance criteria for an outsourcing engagement are objective, quantifiable, and collectible at a reasonable cost, and should be metrics which can be benchmarked against performance of other organizations and providers (Ramarapu, Parzinger and Lado 1997; Kleepes and Jones 1999).

From a different perspective, obstacles such as poor choices of sourcing partners, inadequate planning and training/skills needed to manage outsourcing activities and poor organizational communication have also been identified as impacting the success of outsourcing projects (Lau and Hurley 1997; Guterl 1996; Foster 1999; Laabs 1998 SMART and PESTEL

\subsubsection{Right outsourcing partners}

Choosing the right Outsourcing partners gives an organization exposure to vendor specialized systems. Specialization provides more efficiency that allows for a quicker turnaround time and higher levels of quality

\subsection{Challenges of Logistics Outsourcing}

Like any restructuring exercise and management decision making in business, there are risks associated with outsourcing that procurement managers or top management need to consider carefully (Procurement News December,17th,23rd 2003) and these may be; The possibility of over depending on or leveraged by suppliers which make switching costs to other suppliers in future prohibitively expensive. Over a long time, a supplier of outsourced service may become complacent or change ownership and also a risk of a fall in employ morale for fear of being made redundant, confidentiality links of company matters and in some instances loss of intellectual property rights. Eyaa, 2006, says that, high prices being imposed on suppliers due to increasing trends in outsourcing, the demand for suppliers is so high and has pushed the rates being charged by the suppliers to be high. This later increases the costs yet outsourcing is all about helping firms cut costs. Too much expectancy from suppliers as Company employees tend to expect too much from supplier firms as far as service provision is concerned because they are specialists yet things can go wrong once in awhile. Such issues should not be ignored. Manzi, 2005, according to him, there is a possibility that vital company information may be at a risk of being linked to the company's competitors which is dangerous since some suppliers may be spies to the company.

\subsection{Knowledge Gap}

The literature review reveals that a lot of research has been conducted on the effect of Logistics Outsourcing on Organization's performance across time, across countries and across industries. Some studies concluded that Logistics Outsourcing had strong positive influence on profitability; others concluded negative influence while others recorded a neutral relationship. There seems to be a revelation that the relationship between Logistics Outsourcing and financial performance of firms using the philosophy is not generalizable, but case dependent. The literature has therefore clearly demonstrated that there is no study done to establish the relationship between the adoption Logistics Outsourcing and organizations performance measured by financial performance of tea processing industry in Kenya. This study will be conducted to fill this gap.

\subsection{Research Design}

\section{Research Methodology}

The study adopted a descriptive survey design in determining the outsourced logistics practices among tea processing firms in Bomet County. Gay (1999) describes a survey as an attempt to collect data from members of a population in order to determine the status of that population with respect to one or more variables. 


\subsection{Target Population}

The population of the study consisted of all the 4 tea processing firms and 22 Tea factories in Bomet County. These firms are concentrated in the entire county. The firms have a number of factories and can be classified under two main sectors; locally owned and multinationals.

\subsection{Sampling Frame}

The tea processing firms have a total of 560 employees who are based at their offices, are spread across the county and are working in different divisions. This formed the sampling frame for the study.

\subsection{Sampling design and Sample Size}

The research will employee stratified random sampling in selecting respondents since tea processing firms have a large number of employees. $10 \%$ of the 560 employees that is 56 employees will participate in the study. In a similar study conducted by Bichangi and Karani (2012) a sample study of $10 \%$ was used.

\subsection{Data Collection Instruments and Methods}

This research used both primary and secondary data from tea processing firms in Bomet County. The research used both quantitative and qualitative data to provide complete analysis and give plausible findings. Various data collection methods for qualitative research were reviewed for use in this study (Walker, 1985). Primary data was collected through observation and by use of questionnaires while secondary data was collected from past financial reports, journals and books. Questionnaires were administered to directors, Heads of divisions, managers, officers and clerks with structured questions based on Logistics outsourcing. The questionnaire was framed in English since it's the official language in Kenya.

\subsection{Data Processing and Analysis}

After the data was collected, it was edited for completeness and consistency, descriptive data analysis was used to analyze the data. The method helped in explaining the logistics practices adopted by the tea processing firms, the drivers influencing the practice of logistics outsourcing and the challenges faced by the firms. Frequencies, percentages and proportions were used to establish the number of firms and factories practicing outsourcing.

\subsection{Ethical Considerations}

The capture of information required was done in a legally accepted way. No respondent was coerced into giving out information either by force or by reward. The participation was solely at the discretion of the participants. The information got was specifically for research purposes and such information was not be used in any other manner.

\subsection{Introduction}

\section{Research Findings And Discussions}

This chapter focuses on presentation and interpretation of data. Accordingly it provides general information about the characteristics of the tea processing firms in Bomet County, Kenya.

\subsubsection{Demographic Characteristics}

Four tea processing firms and 52 tea factories were chosen to represent the entire population of tea processing firms in the County of Bomet. Out of these all the 4 tea processing firms and 42 tea factories responded respectively. This provided a $100 \%$ response rate for tea processors and a $76.47 \%$ response rate for the tea factories, hence providing an overall approximate response rate of $75 \%$ (see appendix IV) of the study population which was found to be sufficient for further analysis. The respondents were mainly General Managers, Logistics managers, distribution and warehouse Managers, factory Managers and their supervisors; they all indicated that they had served the organization for more than 10 years. 


\begin{tabular}{|c|c|c|c|c|c|}
\hline 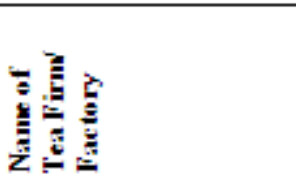 & 裹言 & 醇 & 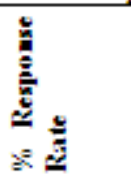 & 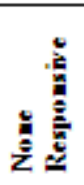 & 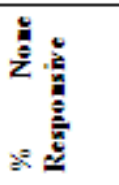 \\
\hline KTDA & 3 & 2 & 67 & 1 & 33 \\
\hline Mogogosiek Tea factory & 2 & 2 & 100 & 0 & 0 \\
\hline Kapkatet Tea Factory & 2 & 1 & 50 & 1 & 50 \\
\hline Tegat Tea Factory & 2 & 2 & 100 & 0 & 0 \\
\hline Momul Tea factory & 2 & 2 & 100 & 0 & 0 \\
\hline Toror Tea Factory & 2 & 2 & 100 & 0 & 0 \\
\hline Kapkoros Tea Factory & 2 & 1 & 50 & 1 & 50 \\
\hline Tirgaga tea Factory & 2 & 2 & 100 & 0 & 0 \\
\hline Rorok Tea Factory & 2 & 2 & 100 & 0 & 0 \\
\hline Total & 19 & 16 & $84 \%$ & 3 & $16 \%$ \\
\hline Unilever Tea Kenya & 3 & $\overline{2}$ & $67 \%$ & 1 & $33 \%$ \\
\hline Chagaik Factory & 2 & 1 & 50 & 1 & 50 \\
\hline Jamji Factory & 2 & 1 & 50 & 1 & 50 \\
\hline Kericho Factory & 2 & 2 & 100 & 0 & 0 \\
\hline TagabiFactory & 2 & 1 & 50 & 1 & 50 \\
\hline Kimugu factory & 2 & 2 & 100 & 0 & 0 \\
\hline Kimari Factory & 2 & 1 & 50 & 1 & 50 \\
\hline Total & 15 & 10 & $67 \%$ & 5 & $33 \%$ \\
\hline TWilliamson Tea & 3 & 2 & $67 \%$ & $\overline{1}$ & $33 \%$ \\
\hline Changoi Tea Factory & 2 & 1 & 50 & 1 & 50 \\
\hline Total & 5 & 3 & 60 & 2 & 40 \\
\hline Finlay's & 3 & 3 & 100 & 0 & 0 \\
\hline Saosa factory & 2 & 1 & 50 & 1 & 50 \\
\hline Mara Mara Instant & 2 & 2 & 100 & 0 & 0 \\
\hline Kymulot factory & 2 & 1 & 50 & 1 & 50 \\
\hline Koros Factory & 2 & 1 & 50 & 1 & 50 \\
\hline Kitumbe Factory & 2 & 1 & 50 & 1 & 50 \\
\hline Chomogonday Factory & 2 & 2 & 100 & 0 & 0 \\
\hline Changana factory & 2 & 2 & 100 & 0 & 0 \\
\hline Total & 17 & 13 & $76 \%$ & 4 & $24 \%$ \\
\hline Grand Total & 56 & 42 & $75 \%$ & 14 & $25 \%$ \\
\hline
\end{tabular}

Source: Researcher Data

\subsubsection{Ownership Structure}

Respondents were requested to indicate the level of their tea processing firm whether, local or foreign owned or both foreign and locally owned. A firm'sdecision to outsource its logistics functions may result from several factors or levels of management. The decisions may be as a result of the level of the firms ownership, whether local or foreign owned or both foreign and locally owned. Strategic objectives may also impact on an organization to outsource its logistics operations.

Table 4.1.2 Level of Ownership of the Tea Processing Firm

\begin{tabular}{|l|c|c|}
\hline Ownership & Frequency & Percentage (\%) \\
\hline Foreign Owned & 30 & 65.22 \\
\hline Locally Owned & 16 & 34.78 \\
\hline Both Foreign and Locally Owned & 0 & 0 \\
\hline Total & $\mathbf{4 6}$ & $\mathbf{1 0 0}$ \\
\hline
\end{tabular}

Source: Researcher Data

$65.22 \%$ of the respondents indicated that their firms are fully foreign owned thus, pausing a likely hood of the fact that the firms were driven to logistics outsourcing by their international policy on the management of logistics function. $34.78 \%$ of the firms on the other hand are locally

Owned this, gives an impression that the firms have not been keen to outsource their logistics function since the decision making organ is local. The respondents also indicated that none of them had both local and foreign ownership status. 


\subsubsection{Number of Years in tea processing Operation}

The number of years a firm has been operating can influence its decision of whether to outsource its logistics operations or not. The table below provides survey information obtained from respondents who were required to provide information on the number of years their tea processing firms have been in business.

Table 4.1.3 Number of Years in Operation

\begin{tabular}{|l|l|l|}
\hline Number of Employees & Frequency & Percentage (\%) \\
\hline $0-50$ & 0 & 0 \\
\hline $51-100$ & 0 & 0 \\
\hline 0 ver 100 & 46 & 100 \\
\hline Total & 46 & 100 \\
\hline
\end{tabular}

Source: Researcher Data

The respondents were required to provide information of an approximate number of employees in the logistics function. A firm that has outsourced its logistics function is expected to have optimum number employees in the function so as to benefit from a reduction on operational costs.

Organizations are currently embarking on reducing their administrative costs as a means to profitability as well as a strategic tool. $100 \%$ of the surveyed tea processors indicated that their companies had more than 100 employees in their businesses. This was a clear indication that as much as other indicators showed that the tea firms were practicing outsourced logistics, engaging a large number of employees may not help a firm to achieve its objective to cost reduction. However, the fact that the tea firms have more than 100 employees does not necessarily mean excess employees.

Approximately $73.9 \%$ of the firms were reported to have been operating in the tea sector for more than 20 years while, $4.3478 \%$ of the firms were reported to have been operating for between 10-20 years and $21.7391 \%$ of them had operated for between 1-10 Years. This is an indication that they fully understand what is to be outsourced and what not to be outsourced. The experience that a firm has had in business may dictate its ability to make sound and effective outsourcing decisions as compared to a firm that has made logistics outsourcing decisions based on benchmarking information alone.

\subsection{Drivers of Logistics Outsourcing}

There are many drivers that can influence an organizations decision to outsource its logistics operations. The respondents were asked to rate the extent to which some listed logistics outsourcing drivers contributed to the firms decision to outsource its logistics operations. This was in a likert scale ranging from (1) Very Small Extent, (2) Small Extent (3) Some Extent, (4) Great extent (5) Very great Extent. Table 4.2 presents the views of the respondents in relation to what is driving the firms towards outsourced logistics operations.

Table 4.2: Logistics Outsourcing drivers

\begin{tabular}{|c|c|c|c|}
\hline 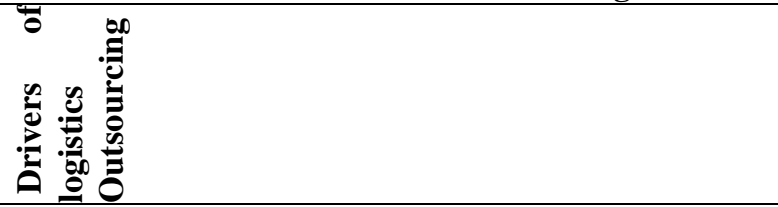 & $\sum_{\Sigma}^{\tilde{E}}$ & 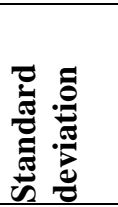 & 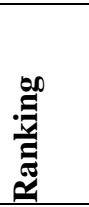 \\
\hline Outsourcing reduces overhead costs & 3.6 & 4.54 & 1 \\
\hline Availability of third party logistics providers & 3.4 & 4.41 & 2 \\
\hline Global best practices & 3.3 & 4.37 & 3 \\
\hline Lack time to perform such activities & 3.2 & 4.35 & 4 \\
\hline To avail more time for other activities & 3.2 & 4.35 & 4 \\
\hline Globalization of business & 3.2 & 4.35 & 4 \\
\hline Availability of a supportive infrastructure & 3 & 4.18 & 7 \\
\hline Logistic activities are non-core to the firm & 3 & 4.18 & 8 \\
\hline Government policy & 3 & 4.18 & 8 \\
\hline Lack of internal expertise to perform logistic functions & 2.8 & 3.75 & 10 \\
\hline Company policy at National/international level & 2.7 & 3.36 & 11 \\
\hline So as to make use of technology and innovation & 2.7 & 3.36 & 11 \\
\hline The availability of a partner to provide a better service & 2.5 & 3.24 & 13 \\
\hline So as to Improve productivity & 2.4 & 2.97 & 14 \\
\hline
\end{tabular}

Source: Researcher Data 
4.54 of the respondents are in agreement of the fact that logistics outsourcing is driven by the urge to reduce overhead costs while 4.41 of the respondents indicated that the availability of third party logistics outsourcing service providers has driven their firms to outsource their logistics operations, 4.37 of the respondents are also in agreement that logistics outsourcing is an accepted best practice in the management of logistics, 4.35 of the respondents believe that logistics outsourcing is driven by the need to create time for other business areas in addition 4.35 of the respondents indicated that logistics outsourcing is a globally accepted business practice and that logistics outsourcing is driven by the fact that once the logistics operations are outsourced more time is utilized in other sectors. 4.18 are in view of the fact that there exists the necessary infrastructure to enable outsourced logistics another 4.18 of the respondents appreciate the fact that the government supports the use of third party service providers on logistics. 4.18 of the respondents are in agreement that lack of internal expertise to handle the logistics function , 3.75 are in agreed that company policy at local and international level is a drive to logistics outsourcing. 3.36, of the respondents agreed that the adoption of technology and innovation drove the firms to outsource logistics operations 3.24, the availability of a partner was , the urge to improve productivity was rated at a low of 2.97 .

\subsection{The Practice Of Logistic Outsourcing}

The practice of logistics outsourcing has seen many firms successfully managing their logistics operations. Respondents were asked to rate the extent to which the listed logistics outsourcing practices impact on firms need to outsource its logistics operations. This was in a likert scale ranging from (1) Very Small Extent, (2) Small Extent (3) Some Extent, (4) Great extent (5) Very great Extent. Table 4.3 presents the views of the respondents in relation to what practices firms utilize as they embarked on outsourced logistics operations.

Table 4. 3: Modes of Logistics operations

\begin{tabular}{|c|c|c|c|}
\hline 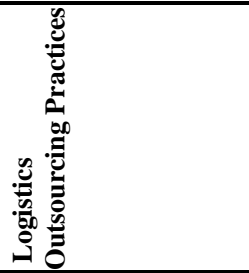 & $\begin{array}{l}\frac{\pi}{\tilde{\Xi}} \\
\sum_{0}^{\circ} \\
0^{\circ}\end{array}$ & 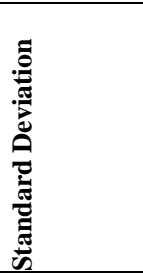 & 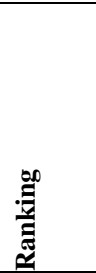 \\
\hline Warehousing & 67.5 & 69.35 & 1 \\
\hline Fleet Management & 67.5 & 69.35 & 1 \\
\hline Fleet Operations & 67.5 & 69.35 & 1 \\
\hline Transport & 62.5 & 65.65 & 4 \\
\hline Distribution & 57.5 & 58.90 & 5 \\
\hline Fleet Maintenance & 40 & 51.95 & 6 \\
\hline Logistics Operations & 0 & 0 & 7 \\
\hline
\end{tabular}

Source:Researcher Data

Based on the foregoing results from the respondents approximately $67.5 \%$ of the respondents indicated that their firms have outsourced their warehousing, fleet management and fleet operations. $62.5 \%$ of the respondents indicated that they have outsourced their Transport operations, while $57.5 \%$ preferred outsourcing their distribution function. Fleet maintenance, warehousing and transport management are the least preferred outsourced functions with a $40 \%$ and $0 \%$ preference rate. This provided an overall logistics outsourcing preference rate of approximately $52 \%$.

Table 4.4: Logistics Outsourcing Practices

\begin{tabular}{|c|c|c|c|}
\hline 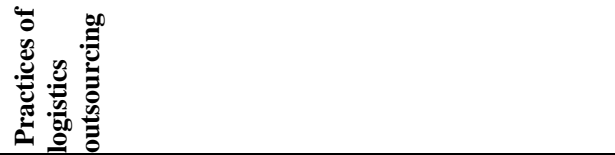 & $\sum^{\Xi}$ & 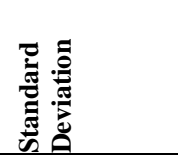 & 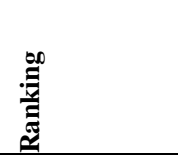 \\
\hline Have both an in-house logistics department & 3.375 & 4.2 & 1 \\
\hline Hires logistics services during peak seasons? & 3.375 & 3.9 & 1 \\
\hline Rely on logistics services used by competitors & 3.375 & 3.6 & 1 \\
\hline Contracted a third part to manage its logistics services & 3.125 & 3.5 & 4 \\
\hline Mergers and acquisitions & 2.875 & 3 & 5 \\
\hline Owns a logistics subsidiary & 2.875 & 2.9 & 5 \\
\hline Practice E-outsourcing & 2 & 2.85 & 7 \\
\hline Strategic alliances with logistic service providers & 0 & 0 & 8 \\
\hline
\end{tabular}

Source: Researcher (2011) 
In a likert scale of (1) Very Small Extent, (2) Small Extent (3) Some Extent, (4) Great extent (5) Very great Extent,Respondents were requested to indicate their level of agreement with the above factors stating with the least accepted to the most accepted practice. The results of the survey indicated that most tea firms preferred (standard deviation of 4.2) to practice both in-house and outsourcing logistics practice, 3.9 standard deviation preferred hiring of logistics services during peak seasons and the use of logistics service providers used by competitors was a prevalent practice. Other practices that the tea firms utilized included contracting third party service providers as well as owning a logistics subsidiary to handle the same, mergers and acquisitions. E- Outsourcing was reported as a rare preference for most tea firms while, strategic alliances with logistics service providers is not practiced at all.

\subsection{The Challenges of Logistics Outsourcing}

Respondents were required to rate in a likert scale the challenges faced by the tea processing firms in their endeavor to outsource logistics operations. As a result of this the respondents' views are presented in the table 5 below:

Table 4.5: Logistics Outsourcing Challenges

\begin{tabular}{|c|c|c|c|}
\hline 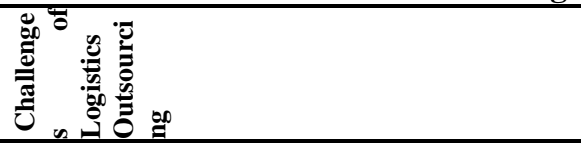 & छ્⿷ & 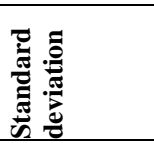 & 央 \\
\hline Loss of control on logistics functions & 3.8 & 4.54 & 1 \\
\hline Industrial unrest & 3.8 & 4.54 & 1 \\
\hline Disintegration of internal conflict & 3.3 & 3.9 & 2 \\
\hline Loss of employee loyalty & 3.2 & 3.9 & 3 \\
\hline Low quality of work & 2.9 & 3.5 & 4 \\
\hline Switching cost & 2.8 & 3.3 & 5 \\
\hline Information leakage occurs from service providers & 2.6 & 3.2 & $\overline{6}$ \\
\hline Over reliance on external parties & 2.6 & 3.2 & 6 \\
\hline Over reliance on service providers & 2.4 & 2.8 & $\overline{7}$ \\
\hline There is loss of command on service delivery & 1.8 & 2.6 & 8 \\
\hline
\end{tabular}

Source:Researcher Data

With a 4.54 standard deviation agreement level, the respondents indicated that Loss of control on logistics operations and industrial unrests were the most prevalent of the challenges the tea firms were facing. These were followed by a 3.9 standard deviation rate in agreement that the disintegration of internal conflict and loss of employee loyalty. 3.5 of the respondents reported that the quality of work also deteriorated the effects of switching costs and information leakage as well as overreliance on third party service providers. Loss of command on service delivery was the least prevalent among the challenges reported by the respondents.

\subsection{Introduction}

\section{Summary, Conclusions And Recommandations}

This chapter summarizes the research findings it also presents conclusions and recommendations of the study. The conclusions were drawn from the findings of the study in line with the study objectives. The study sought to establish the drivers of logistics outsourcing, the practices of logistics outsourcing and the challenges faced by tea processing firms in Bomet County, Kenya.

\subsection{Summary}

The study findings may have long term implications for tea processing firms in the management of their logistics, given the ever changing business environment and the global economic challenges facing businesses the world over. The tea sector just like any other business sectors has to embrace modern best business practices so as to survive. To do this there will be need to engage every available resource in the most optimal way so as to realize the ensuing benefits of logistics outsourcing. The major areas to consider among the tea processing firms are the driving forces to logistics outsourcing, the practices of logistics outsourcing and the challenges the tea firms face in the management of logistics operations.

\subsection{Conclusion}

There is a very strong relationship between drivers and logistics outsourcing practices. This research finds a positive effect of financial incentives, focus on core competency and globalization on logistics outsourcing practices in tea processing firms in Bomet County 


\subsubsection{Drivers of Logistics Outsourcing}

The researcher sought to establish the drivers of logistics outsourcing among tea processing firms in Bomet County Kenya. After surveying and evaluating several tea processing firms and factories, it was found out thatmost firmshave been drivento logistics outsourcing by the urge to reduce the cost of doing business, secondly the availability of third party service providers also motivated firms to outsource their logistics operations, thirdly outsourcing is viewed as a global best business practice;fourthly the urge to concentrate on core business activities. Globalizationof business and availability of a supportive logistics infrastructure, fifthly logistics functions are non-core to the tea processing firms and the fact that government policies do not inhibit the firms from adopting outsourced logistics.

Some tea processors also indicated that they do not have the expertise to handle their logistics activity and hence preferred to outsource the functions. Others indicated that the drive to outsource was part of their international policy, the need to take advantage of technology and innovation was also indicated as a drive by some firms to outsource their logistics operations. The drive to improve productivity was the least preferred driver to logistics outsourcing. Much as some traits of logistics outsourcing drivers have been evidenced in most of the tea processing firms and factories, most of the firms are yet to appreciate the adoption of these drivers for the success of their businesses.

For example most of the firms reported that their main reason to outsource was the urge to reduce cost while, others were motivated by the availability of outsourcing or 3 party logistic service providers, an impressing factor was that some of the firms were driven by the desire to adopt it as gesture to adopt internally accepted best practices.Clearly this is a sign that firms in the tea sector are concerned about the values of Globalization of businesses which is one of the major tenets of strategic business operations.

\subsubsection{The Practice of Logistic Outsourcing}

The results of the analysis clearly indicate the level of adoption of a logistics outsourcing practice among the tea processing in Bomet County Kenya. The results of the survey provided an insight on the extent to which the tea firms practice both in-house and outsourcing logistics practice. Hired logistics services during peak seasons and the use of logistics service providers used by competitors was a prevalent practice adopted by the tea processors, hence giving an indication of the level of logistics outsourcing practices being adopted by the tea processors.

Other practices that the tea firms have been utilizing included contracting third party service providers (3PL), as well as owning a logistics subsidiaries to handle some specific tasks, mergers and acquisitions have also been viewed as potential strategic practices. E- Outsourcing was reported as a rare preference for most tea firms probably due to lack of supportive infrastructure within the markets. Strategic alliances with logistics service providers is not practiced at all this may be the practice of the future given that currently the tea firms are even not scared of sharing service providers. This may be an acceptable practice in the short term but once competition strikes the firms will begin to venture into strategic business alliances so as to curb the effects of business competition.

The management of the firms need to invest more by acquiring knowledge and skill on the management of the logistics function. They may in addition seek to invest more on research and develop stronger and long-term ties with the logistics service providers. This is mainly because the survey does not give any clue about long-term synergistic relationship. When firms or individuals partner in any mutual understanding, they double their efforts with other accompanying benefits.

\subsubsection{The Challenges of Logistics Outsourcing}

In the middle of every success there will always be challenges, but the challenges must be viewed as positive indicators for continuous improvement. During the survey respondents agreed that in did logistics outsourcing is not without challenges. The challenges that were highlighted included; Loss of control on logistics operations and industrial unrests were the most prevalent of the challenges that were being faced by the tea processing firms. These were followed by disintegration of internal conflict and loss of employee loyalty. Respondents reported that the quality of work was found to be deteriorating, the effects of switching costs and information leakage as well as overreliance on third party service providers. Loss of command on service delivery was the least prevalent among the challenges reported by the respondents.

As an objective measure towards logistics outsourcing and as a means towards continuous improvement, firms need to appreciate the challenges that come along with the package of successful adoption of new ways of doing business. The unfolding events can be referred to as indicators to the successful implementation of an outsourced logistics practice. If progressively monitored and used as corrective benchmarks, through to the implementation these logistics outsourcing practices and challenges will enable the tea processing firms to fully adopt outsourced logistics practices thereby achieve their key objective of cost reduction. The management of tea processing firms will have to adopt current management skills and techniques 
such as business process re-engineering as well as change management skills so as to ensure that that benefits of logistics outsourcing are realized without jeopardizing the livelihoods of employees and other stakeholders.

\subsection{Recommendations}

Based on the findings, logistics outsourcing should be supported by all departments of the organization so as to get the best of the benefits of outsourcing in the organization. To achieve success, we always have to stand together to share ideas for better organizational performance. Management support is paramount in aligning the entire organization rally behind outsourcing. Any activity in the company done without management consent and support is a manifestation of failure in that activity.

Change management is critical success factor of logistics outsourcing helping to deal with change, both from the perspective of an organization and on the individual level. A somewhat ambiguous term, change management has at least three different aspects, including: adapting to change, controlling change, and effecting change Properly defined performance criteria for an outsourcing engagement are objective, quantifiable, and collectible at a reasonable cost, and should be metrics which can be benchmarked against performance of other organizations and providers

Choosing the right Outsourcing partners gives an organization exposure to vendor specialized systems. Specialization provides more efficiency that allows for a quicker turnaround time and higher levels of quality The outsourcing transition phase may also fail if schedules and budgets are not achieved because of insufficient planning and/or resources. An outsourcing project must be run with the same discipline and planning as a wellrun large-scale systems implementation. Outsourcing is a replacement of production or service functions, and these functions have a direct bearing on the company's ability to meet its commitments to customers and shareholders

Effective communication among cross-functional areas reduces the negative effects of outsourcing projects on the morale and performance of the remaining employees. Management must step in and rebuild trust among the workers, and jobs may need to be reevaluated and expanded or changed to fit the new organization. This can be achieved through support and involvement of top management and by providing incentives to employees and vendors who meet and exceed the contracted performance expectations (Jones 1997; Foster 1999).

\subsection{Areas for further Research}

The study has opened up a number of gaps that can be addressed in further research, firstly the study covered tea processing in Bomet County, yet there are other tea belts such as Kisii and Nyeri, Kiambu, Muranga Embu and Meru which may require a study of their own. Secondly there will be need for further research on the management of logistics outsourcing on the larger agricultural sector.

\section{References}

[1]. Africk, J.M. ,\&Markeset, E. (1996).Making contract logistics work. Transportation \& Distribution, January, pp. 58-60

[2]. Bardi, E.J. \& \& Tracey, M. (1991). Transportation outsourcing: a survey of US practices, International Journal of Physical Distribution \& Logistics Management. Vol. 21 No. 3, pp. 15.

[3]. Bhatnagar, A.S. ,\& R. Millen (1999). Third party logistics services: a Singapore perspective, "International Journal of Physical Distribution \& Logistics Management, vol. 29 No. 9, pp. 569-587.

[4]. Bingham, D. (1994). Take a fresh look at your logistics strategies. Transportation \& Distribution, March, pp. 58-60.

[5]. Bowman, R.J.(1994). Three's a crowd. Distribution\& Logistics Management, August, pp. 78-81.

[6]. Bradley, P. (1994c). Contract logistics: it's all about costs.Purchasing, 20 October, pp. 3-14.

[7]. Bradley, P. (1995b). Buying third-party services? Beware the bells and whistles.Traffic Management, December, p. 24.

[8]. Byrne, P.M. (1993). A new road map for contract logistics. Transportation \& Distribution, April, pp. 58-62

[9]. Kirui, (2001).Competitive advantage through outsourcing of non -core Logistics activities within the supply Chain of British American Tobacco, Kenya", Unpublished MBA Project.

[10]. Lacity, M.C., Wilcoks, L.P. ,\&Feeny, D.F. (1995). IT outsourcing.Maximize flexibility and Control. Harvard Business Review, May-June, pp. 86-7.

[11]. Lieb, R.C. (1992). The use of third-party logistics services by large American manufacturers. Journal of Business Logistics, Vol. 13 No. 2, pp. 29-42.

[12]. Maltz, A.B. (1994), Outsourcing the warehousing function: economic and strategic Considerations Logistics and Transportation Review, Vol. 30 No. 3, pp. 245-65.

[13]. Journal of Business Logistics, Vol. 11 No. 2, pp. 27-39.

[14]. Sink, H.L. and Langley, C.J. Jr (1997). A managerial framework for the acquisition of third- party logistics services. Journal of Business Logistics, Vol. 18 No. 2, pp. 163-89.

[15]. Tea processing Firms in Bomet, County http://www.teaboard.or.ke

[16]. Trunick, P.A. (1989). Outsourcing: a single source for many talents. Transportation \& Distribution, July, pp. 20-23.

[17]. Trunick, P.A. (1992). Carving a niche in global logistics. Transportation \&Distribution, February, pp. 57-8. Vol. 17 No. 1, pp. $305-$ 20. 